\title{
25 Years Geneva Association An Unprecedented Period of Fundamental Change in Insurance Business
}

\author{
by Herbert Schimetschek*
}

Since the foundation of the Geneva Association in the year 1973 the insurance business world-wide became one of the key activities of modern economy. The Geneva Association and its members made an important contribution to this development offering an opportunity for the top Chief Executives of major insurance companies to exchange ideas and discuss strategic key issues. In a time of a rapid changing economic environment the Geneva Association offers for insurance companies an international unique and indispensable forum to study and explore the future potential of our industry.

During the past 25 years, the Geneva Association - by means of its research activities and its recognized publications - was able to acquaint a broad public as well as experts and representatives of all important fields of economics and politics with the fundamental role of the insurance industry in today's economics. The results of those research activities serve as a basis for the assessment of new developments in the insurance industry, be it from the practical as well as from the political point of view; they are the principles for the strategic visions of the insurance sector.

I would like to cite just two issues as examples, out of a great number of very substantial and important contributions.

With the "Four Pillars" Research Program and the studies dealing with the notion and practice of insurability in the case of Enviromental Issues the Geneva Association has supported with its studies the important position of the insurance industry in two of the most relevant and essential questions of today's society.

${ }^{1}$ President of the Comité Européen des Assurances, Paris, and Chairman of the Board of BARC Insurance-Holding, Vienna. 
The "Four Pillars" Research Program launched in 1987 searching for some solutions to the issue of the future financing of social security has enriched the discussion of the ageing process, the cost of medicine and the sustainability of traditional welfare programs with a series of new and interesting approaches.

With the studies concerning the notion and practice of insurability and the case of Environmental Issues and their relevance for the field of insurance it was possible to consolidate the acknowledgement of the insurance companies as experts for economic issues. Due to these activities, the expertise of the insurance industry in the evaluation of the vulnerabilities linked to environmental topics and questions related to possible climate changes is nowadays uncontested. Today the voice and the opinion of private insurance companies regarding those topics has a scientific background and cannot be overheard, and that's also because of the Geneva Association.

It is an honour for me to thank all the collaborators of the Geneva Association as well as all those who gave their contributions during the past 25 years: I thank them for their important work and wish them good luck for the future. They did exceptionally well bridging the gap between the academic and the economic world in a way that is stimulating for us all and will be of still bigger importance to the insurance industry in the years to come. 